\title{
Longitudinal melanonychia and distal onycholysis associated with 5-fluorouracil/adriamycin/cyclophosphamide chemotherapy for breast cancer
}

\section{Podłużna melanonychia i dystalna onycholiza związana z leczeniem chemioterapią 5-fluorouracyl/adriamycyna/cyklofosfamid z powodu raka piersi}

\author{
'Department of Oncology, Military Institute of Medicine, Warsaw, Poland \\ ${ }^{2}$ Department of Dermatology, Military Institute of Medicine, Warsaw, Poland \\ ${ }^{3}$ Department of Oncology, European Health Center, Otwock, Poland \\ 'Klinika Onkologii, Wojskowy Instytut Medyczny, Warszawa, Polska \\ ${ }^{2}$ Klinika Dermatologii, Wojskowy Instytut Medyczny, Warszawa, Polska \\ ${ }^{3}$ Oddział Onkologii Kinicznej, Europejskie Centrum Zdrowia, Otwock, Polska
}

Marta Żywno', Agnieszka Terlikowska-Brzósko², Witold Owczarek², Cezary Szczylik³

CORRESPONDING AUTHOR/ ADRES DO KORESPONDENCJI:

lek. Marta Żywno

Klinika Onkologii

Wojskowy Instytut Medyczny

Warszawa, Polska

E-mail: marcia65@wp.pl

\begin{abstract}
Introduction: Longitudinal melanonychia presents with pigmented longitudinal streaks of the nail plate. It results from an increased activity of melanocytes or melanocytic hyperplasia in the nail matrix or nail bed and is associated with increased melanin deposition in the nail plate. Distal onycholysis is characterized by separation of the distal part of the nail plate from the nail bed.

Objective: To present a case of longitudinal melanonychia and distal onycholysis associated with 5-fluorouracil/adriamycin/cyclophosphamide chemotherapy.

Case report: A 66-year-old woman, who received 5-fluorouracil/adriamycin/cyclophosphamide for breast cancer developed longitudinal melanonychia and distal onycholysis. After discontinuation of chemotherapy, nail changes improved significantly.

Conclusions: Drug-induced longitudinal melanonychia and distal onycholysis are common adverse effects of breast cancer chemotherapy. This case shows that lesions may resolve after discontinuation of therapy.
\end{abstract}

Key words: adriamycin, breast cancer, cyclophosphamide, melanonychia, 5-fluorouracil.

\section{STRESZCZENIE}

Wprowadzenie: Podłużna melanonychia objawia się ciemnymi, podłużnymi pasmami na płytce paznokciowej i jest spowodowana zwiększoną aktywnością melanocytów macierzy lub łożyska paznokcia albo lub ich lokalną proliferacją. Wiąże się ze zwiększonym odkładaniem melaniny w płytce paznokciowej. Onycholiza dystalna to oddzielenie się dystalnej części płytki paznokciowej.

Cel pracy: Przedstawienie przypadku podłużnej melanonychii i onycholizy dystalnej u pacjentki leczonej chemioterapią według schematu 5-fluorouracyl/adriamycyna/cyklofosfamid. 
Opis przypadku: U pacjentki w wieku 66 lat, leczonej chemioterapią według schematu 5-fluorouracyl/adriamycyna/cyklofosfamid z powodu raka piersi zaobserwowano podłużną melanonychię i dystalną onycholizę. Zmiany ustąpiły po zakończeniu chemioterapii.

Wnioski: Przebarwienia płytki paznokciowej, w tym podłużna melanonychia, są częstymi objawami niepożądanymi chemioterapii raka piersi. Ten przypadek pokazuje, że zmiany mogą ustąpić po zakończeniu leczenia.

Słowa kluczowe: adriamycyna, cyklofosfamid, melanonychia, rak piersi, 5-fluorouracyl.

\section{INTRODUCTION}

Longitudinal melanonychia is characterized by brown or gray to black nail pigmented bands extending between the nail matrix and distal nail margin [1]. Melanocyte activation is one of the two major causes of melanonychia [1]. The second cause is benign or malignant melanocyte proliferation [1].

Diagnosis of melanonychia includes physical and dermoscopic examination of all nails, an inspection of the free edge of each nail, periungual area and the rest of the skin as well as oral and genital mucous membranes [2]. If there is a clinical suspicion of onychomycosis, direct microscopic examination and mycological culture should be performed [3].

Drugs are a common cause of nail and cutaneous pigmentations, mostly due to melanocyte activation $[1,4]$. Drug-induced melanonychia is usually polydactylic $[1,5]$ and appears as longitudinal or transverse nail bands, or diffuse nail pigmentation [1] within a wide range of time (weeks to years) after drug administration [5].

Detachment and lifting of a nail plate from a nail bed may be distal (onycholysis) or proximal (onychomadesis), primary (idiopathic) or secondary [6]. Diagnosis of onycholysis, apart from clinical examination and onychoscopy, includes bacteriological and mycological examinations and a nail apparatus biopsy in doubtful cases. Treatment of onycholysis depends on its cause.

\section{OBJECTIVE}

By this case report authors aimed to draw attention to co-existence of longitudinal melanonychia and distal onycholysis in cancer patients as a result of specific chemotherapeutic regimen administration.

\section{WPROWADZENIE}

Podłużna melanonychia jest zaburzeniem, które ma postać prążków o barwie brązowej lub szaroczarnej, przebiegających wzdłuż płytki paznokciowej od macierzy do dystalnego wolnego brzegu paznokcia [1]. Jedną z dwóch głównych przyczyn melanonychii jest aktywacja melanocytów [1]. Drugą przyczynę stanowi łagodna lub złośliwa proliferacja melanocytów [1].

Rozpoznanie melanonychii opiera się na badaniu fizykalnym i dermoskopowym wszystkich paznokci, badaniu wolnego brzegu każdej płytki paznokciowej, okolicy okołopaznokciowej, pozostałej skóry, a także błon śluzowych jamy ustnej i narządów płciowych [2]. W przypadku klinicznego podejrzenia grzybicy paznokci należy wykonać bezpośrednie badanie mikroskopowe oraz posiew mykologiczny [3].

Leki są częstą przyczyną przebarwień w obrębie skóry i paznokci, głównie w mechanizmie aktywacji melanocytów [1,4]. Melanonychia indukowana lekami zazwyczaj obejmuje wszystkie paznokcie $[1,5]$ i ma postać podłużnych lub poprzecznych prążków lub rozlanych przebarwień w obrębie płytek paznokciowych [1]. Zmiany pojawiają się w szerokim przedziale czasowym (od tygodni do lat) od zastosowania wywołującego je leku [5].

Oddzielenie i uniesienie płytki paznokcia od łożyska może być dystalne (onycholiza) lub proksymalne (onychomadeza), pierwotne (idiopatyczne) lub wtórne [6]. W rozpoznaniu onycholizy, oprócz badania klinicznego i onychoskopii, wykonywane są badania bakteriologiczne i mykologiczne, a w przypadkach wątpliwych także biopsja aparatu paznokciowego. Leczenie onycholizy zależy od przyczyny zaburzenia.

\section{CEL PRACY}

Celem opisu przypadku jest zwrócenie uwagi na możliwość współwystępowania podłużnej melanonychii i dystalnej onycholizy u pacjentów z nowotworami wskutek stosowania określonego schematu chemioterapii. 


\section{CASE REPORT}

We present the case of a 66-year-old Caucasian female primarily diagnosed with tumor of the left breast in 2007. Core biopsy of the left breast was performed and histopathological examination revealed grade 2, estrogen receptor positive, progesterone receptor positive, human epidermal growth factor receptor 2 (HER2) positive carcinoma ductale infiltrans. Computed tomography scan of the chest, the abdomen and the pelvis showed neoplastic dissemination and stage 4 breast cancer was confirmed. In March 2012 the patient was admitted to the Department of Oncology for starting chemotherapy based on 5-fluorouracil/adriamycin/cyclophosphamide regimen. On admission she presented in a good general condition (Eastern Cooperative Oncology Group - ECOG) 0, Karnofsky $100 \%$ ). Physical examination showed bleeding ulcerated tumor of the left breast, enlarged ulcerated left axillary lymph nodes, varices of the lower extremities and edema of the right lower limb. She did not suffer from any chronic diseases and took no medications.

Two months later, after the $3^{\text {rd }}$ cycle of chemotherapy, nail changes appeared and aggravated with time. All of the nails of hands and feet showed longitudinal melanonychia with variable intensity: extending on the whole length of all the fingernails (fig. 1) and on the proximal half of all the toenails (fig. 2). Additionally, there was distal onycholysis on the $1^{\text {st }}, 2^{\text {nd }}$, and $3^{\text {rd }}$ finger of the right hand and on the 1st finger of the left hand (fig. 3). Beau's lines were detected on the left index finger and the right index and middle fingers. No acute paronychia was recorded. Pseudo-Hutchinson's sign was noted as nail pigmentation was visible through translucent cuticula. Microscopic examination of the hyperkeratotic material from the nail bed confirmed the presence of fungal elements. Mycological culture showed growth of Candida spp. colonies. Cyclopiroxolamine solution was recommended topically twice daily. In August 2012, about 3 months after discontinuation of chemotherapy, we received information from the patient that nail changes had been gradually improving and nearly disappeared.

\section{DISCUSSION}

Female patients with a long period of treatment administered as combination therapy are more susceptible to develop chemotherapy-induced melanonychia [1, 4]. In 1992 Bianchi and coauthors described a case of longitudinal melanonychia after 5-fluorouracil/adriamycin/cyclophosphamide

\section{OPIS PRZYPADKU}

Przedstawiamy przypadek 66-letniej kobiety rasy kaukaskiej, u której w 2007 roku pierwotnie rozpoznano nowotwór lewej piersi. Wykonano biopsję cienkoigłową. W badaniu histopatologicznym stwierdzono carcinoma ductale infiltrans w stopniu II, z ekspresją receptora estrogenowego i progesteronowego oraz ekspresją receptora HER-2 (ludzkiego naskórkowego czynnika wzrostu). W badaniu metodą tomografii komputerowej klatki piersiowej, jamy brzusznej i miednicy wykazano rozsiew nowotworowy i potwierdzono rozpoznanie raka piersi w IV stopniu zaawansowania. W marcu 2012 roku pacjentka została przyjęta do Kliniki Onkologii w celu rozpoczęcia chemioterapii w schemacie 5-fluorouracyl/ adriamycyna/cyklofosfamid. Przy przyjęciu chora była w stanie ogólnym dobrym (stopień sprawności 0 w skali ECOG (Eastern Cooperative Oncology Group), $100 \%$ według skali Karnofsky'ego). W badaniu stwierdzono guz lewej piersi z krwawiącym owrzodzeniem na powierzchni, powiększone, owrzodziałe węzły chłonne pachowe po stronie lewej, żylaki kończyn dolnych i obrzęk w obrębie prawej kończyny dolnej. U pacjentki nie występowały żadne choroby przewlekłe. Nie przyjmowała również żadnych leków.

Dwa miesiące później, po zakończeniu 3. cyklu chemioterapii, pacjentka zauważyła zmiany na paznokciach, które z upływem czasu uległy nasileniu. $\mathrm{Na}$ wszystkich paznokciach rąk i stóp stwierdzono zmiany w postaci melanonychii podłużnej o różnym nasileniu: na całej długości wszystkich płytek paznokciowych rąk (ryc. 1) i na proksymalnej połowie wszystkich paznokci stóp (ryc. 2). Dodatkowo stwierdzono onycholizę dystalną na palcach I-III prawej ręki oraz na palcu I lewej ręki (ryc. 3). Na lewym palcu wskazującym oraz na prawym palcu wskazującym i środkowym obecne były linie Beau. Nie stwierdzono objawów ostrej paronychii. Odnotowano stan imitujący objaw Hutchinsona (pseudo-objaw Hutchinsona): ciemne zabarwienie paznokcia widoczne przez przezroczysty obrąbek naskórkowy. Badanie mikroskopowe masy hiperkeratotycznej pobranej z łożyska paznokcia potwierdziło obecność grzybów. W posiewie mykologicznym wyhodowano kolonie Candida spp. Pacjentce zalecono miejscowe stosowanie roztworu cyklopiroksolaminy 2 razy dziennie. W sierpniu 2012 roku, po upływie około 3 miesięcy od zakończenia chemioterapii, otrzymaliśmy od pacjentki informację, że stan paznokci stopniowo poprawiał się i zmiany niemal całkowicie ustąpiły.

\section{OMÓWIENIE}

Kobiety, u których stosowane jest długotrwałe leczenie skojarzone nowotworów, są bardziej narażone na wystąpienie melanonychii indukowanej che- 


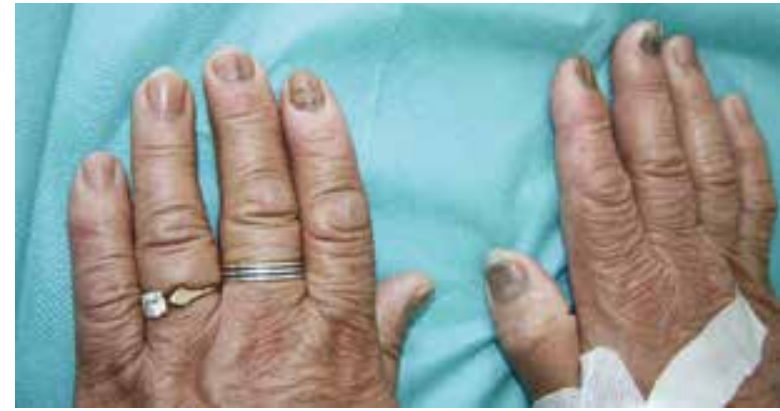

Figure I. Longitudinal melanonychia and distal onycholysis of the fingernails of hands. Multiple longitudinal bands, varying in size, intensity and color from dark-brown to grey-black. All the fingernails were involved, but the most prominent longitudinal melanonychia was visible on the $1^{\text {st }}-3^{\text {rd }}$ fingers of both hands. Distal onycholysis was present on the $\left.\right|^{\text {st }}-3^{\text {rd }}$ fingers of the right hand and on the $\left.\right|^{\text {st }}$ finger of the left hand. Beau's lines were detected on the left index finger and the right index and middle fingers. Chronic paronychia on the index finger of the left hand and on the index and middle fingers of the right hand. Pseudo-Hutchinson's sign was observed

Rycina I. Podłużna melanonychia i dystalna onycholiza w obrębie paznokci rąk. Liczne podłużne pasma o różnej szerokości, intensywności i zabarwieniu (od ciemnobrązowego do szaroczarnego). Zmiany występowały na wszystkich paznokciach rąk, jednak najciemniejsza i najlepiej widoczna była melanonychia na palcach I-II obu rąk. Dystalna onycholiza na palcach I-III prawej ręki i na palcu I lewej ręki. Linie Beau były obecne na lewym palcu wskazującym oraz na prawym palcu wskazującym i środkowym. Przewlekłe zapalenie w obrębie wału paznokciowego lewego palca wskazującego oraz na palcach wskazującym i środkowym ręki prawej. Uwagę zwracał pseudo-objaw Hutchinsona

(FAC) chemotherapy in a breast cancer patient. Three weeks after starting chemotherapy, longitudinal melanonychia occurred in the middle of the nail plates of both thumbs, suggesting the direct effect of chemotherapy on the nail bed melanocytes [7]. On the contrary, our patient had longitudinal stripes on the entire fingernails and on the proximal half of all toenails, suggesting activation of matrix melanocytes. Pigmented lesions usually fade after cessation of the drug or dose reduction $[1,4]$. However, sometimes they never disappear completely due to persistent nail matrix melanocyte activation $[1,4]$. It is also worth mentioning that breast cancer could induce nail hyperpigmentation regardless of chemotherapy [8].

Chemotherapy-induced onycholysis is most frequently associated with regimens based on anthracyclines and taxanes $[9,10]$. Chemotherapy-induced onycholysis predominantly occurs approximately 12 weeks after starting chemotherapy [9]. Nail candidiasis is a quite common complication in immunocompromised patients [2]. Therefore, we presume that candidal onychomycosis occurred secondary to chemotherapy-induced onycholysis in our patient [2].

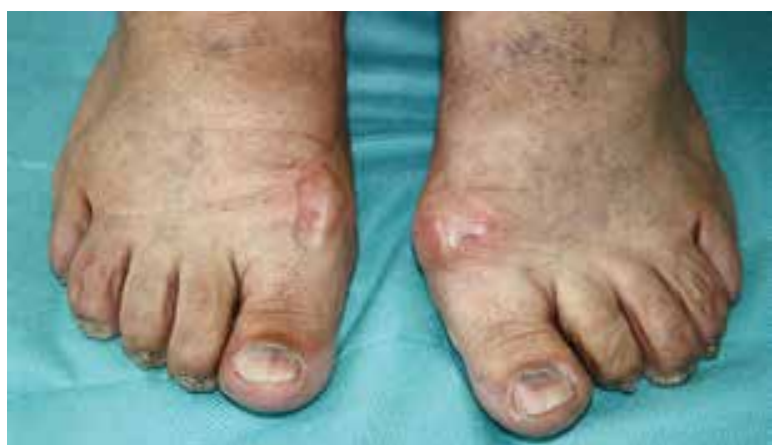

Figure 2. Longitudinal melanonychia of the toenails. Longitudinal dark-brown to grey-black bands were present on all the toenails. Predominance of the diffuse pattern of melanonychia on $2^{\text {nd }}$ to $4^{\text {th }}$ toenails. Only proximal parts of all toenails of both feet were affected by longitudinal melanonychia, which suggests direct effect of systemic chemotherapy on nail matrix melanocytes. Pseudo-Hutchinson's sign was observed on all toenails

Rycina 2. Podłużna melanonychia paznokci stóp. Podłużne ciemnobrązowe i szaroczarne pasma obecne na wszystkich paznokciach stóp. Rozproszony barwnik na paznokciach II-IV stóp. Podłużna melanonychia dotyczyła wyłącznie proksymalnej połowy paznokci obydwu stóp, co sugeruje bezpośredni wpływ chemioterapii systemowej na melanocyty macierzy paznokci. Pseudo-objaw Hutchinsona widoczny na wszystkich palcach stóp

mioterapią [1, 4]. W 1992 roku Bianchi i wsp. opisali przypadek podłużnej melanonychii u pacjentki z rakiem piersi po chemioterapii według schematu 5-fluorouracyl/adriamycyna/cyklofosfamid (FAC). Po 3 tygodniach od rozpoczęcia chemioterapii w środkowej części płytki paznokciowej obu pierwszych palców rąk pojawiła się zmiana w postaci podłużnej melanononychii. Wskazuje to na bezpośredni wpływ chemioterapii na melanocyty w łożysku paznokcia [7]. U naszej pacjentki podłużne prążki wystąpiły na całej długości płytek paznokciowych rąk i na proksymalnej połowie wszystkich paznokci stóp, co sugeruje aktywację melanocytów macierzy paznokci. Zmiany barwnikowe tego typu zwykle ustępują po odstawieniu leku lub obniżeniu dawki $[1,4]$. Zdarza się jednak, że nigdy nie zanikają całkowicie z powodu utrzymującej się aktywacji melanocytów w macierzy paznokci $[1,4]$. Warto w tym miejscu wspomnieć, że rak piersi może wywoływać przebarwienia paznokci, niezależnie od stosowanej chemioterapii [8].

Onycholiza wywołana chemioterapią najczęściej występuje u chorych leczonych chemioterapią opartą na antracyklinach (np. adriamycyną) i taksanach $[9,10]$. Zmiany pojawiają się zazwyczaj po około 12 tygodniach od rozpoczęcia chemioterapii [9]. Dość częstym powikłaniem występującym u pacjentów z obniżoną odpornością jest kandydoza paznokci [2]. Przypuszczamy, że $\mathrm{u}$ przedstawionej pacjentki schorzenie wystąpiło wtórnie do onycholizy wywołanej chemioterapią [2]. 


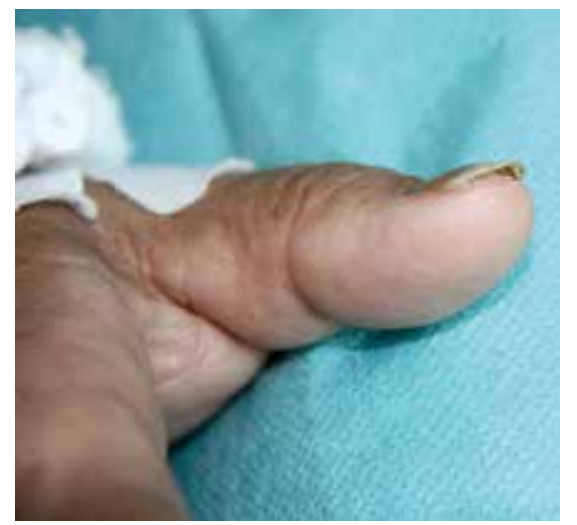

Figure 3. Distal onycholysis of the right thumb. A space under the nail of the right thumb was developed as a result of distal onycholysis

Rycina 3. Dystalna onycholiza paznokcia prawego kciuka. Przestrzeń pod paznokciem prawego kciuka powstała w wyniku onycholizy dystalnej

\section{CONCLUSIONS}

Nail plate hiperpigmanetation, including longitudinal melanonychia are common adverse events of breast cancer therapy [11].

These changes are most commonly induced by docetaxel, but also may be associated with treatment regimen which include cyclophosphamide alone or in combination with adriamycin. Our case indicates that the lesions may resolve after discontinuation of chemotherapy.

\section{CONFLICT OF INTEREST}

The authors declare no conflict of interest.

\section{WNIOSKI}

Przebarwienia płytki paznokciowej, w tym podłużna melanonychia, należą do najczęstszych dermatologicznych objawów niepożądanych chemioterapii raka piersi [11].

Zmiany najczęściej indukowane są docetakselem, ale mogą być również indukowane schematami zawierającymi cyklofosfamid lub cyklofosfamid $\mathrm{z}$ adriamycyną. Nasz przypadek pokazuje, że zmiany mogą ustępować po zakończeniu chemioterapii.

\section{KONFLIKT INTERESÓW}

Autorzy nie zgłaszają konfliktu interesów.

\section{References}

1. Tosti A., Piraccini B., de Farias D.: Dealing with melanonychia. Semin Cutan Med Surg 2009, 28, 49-54.

2. Braun R.P., Thomas L.: Nails. In: Atlas of Dermoscopy. A.A. Marghoob, J. Malvehy, R.P. Braun (eds.). Taylor \& Francis Ltd., London 2012, 268-275.

3. Finch J., Arenas R., Baran R.: Fungal melanonychia. J Am Acad Dermatol 2012, 66, 830-840.

4. Dasanu C.A., Vaillant J.G., Alexandrescu D.T.: Distinct patterns of chromonychia, Beau's lines and melanoderma seen with vincristine, adriamycin, dexamethasone therapy for multiple myeloma. Dermatol Online J 2006, 12, 10.

5. Utas S., Kulluk P.: A case of hydroxyurea-induced longitudinal melanonychia. Int J Dermatol 2010, 49, 469-470.

6. Jadhav V.M., Mahajan P.M., Mhaske C.B.: Nail pitting and onycholysis. Indian J Dermatol Venereol Leprol 2009, 75, 631-633.

7. Dias P.C.R., Miola A.C., Miot H.A.: Successful management of chronic refractory onycholysis by partial nail avulsion followed by topical tretinoin. An Bras Dermatol 2019, 94, 118-119.

8. Krutchik A.N., Tashima C.K., Buzdar A.U., Blumenschein G.R.: Longitudinal nail banding with breast carcinoma unrelated to chemotherapy. Arch Intern Med 1978, 138, 1302-1303. 
9. Hussain S., Anderson D.N., Salvatti M.E., Adamson B., McManus M., Braverman A.S.: Onycholysis as a complication of systemic chemotherapy: report of five cases associated with prolonged weekly paclitaxel therapy and review of the literature. Cancer 2000, 88, 2367-2371.

10. Hudis C., Seidman A., Baselga K., Baselga J.: Sequential high dose adjuvant Doxorubicin (A), Paclitaxel (T), and cyclophosphamide(C) with G-CSF $(\mathrm{G})$ is feasible for women (pts) with resected breast cancer (BC) and $\geq 4(+)$ Lymph nodes (LN) [abstract 62]. Proc Am Soc Clin Oncol 1994, 13, 65.

11. Anoop T.M., Joseph P.R., Mini P.N., Pranab K.P., Gopan G., Chacko S.: Cutaneous toxicities in breast cancer patients receiving chemotherapy and targeted agents--an observational clinical study. Clin Breast Cancer 2021, 21, e434-e447.

Received: 27.05 .2021

Accepted: 5.09.2021

Otrzymano: 27.05.2021 r.

Zaakceptowano: 5.09.2021 r.

How to cite this article

Żywno M., Terlikowska-Brzósko A., Owczarek W., Szczylik C.: Longitudinal melanonychia and distal onycholysis associated with 5-fluorouracil/adriamycin/cyclophosphamide chemotherapy for breast cancer. Dermatol Rev/Przegl Dermatol 2021, 108, 305-310. DOI: https://doi.org/10.5114/dr.2021.110763. 